\title{
Downregulation of transforming growth factor $\beta$ type II receptor in laryngeal carcinogenesis
}

\author{
A Franchi, O Gallo, I Sardi, M Santucci
}

\begin{abstract}
Aims-To investigate whether anomalies of transforming growth factor $\beta$ type II receptor (TGF- $\beta$ RII) expression occur in the early stages of laryngeal carcinogenesis and to assess their importance in the development of laryngeal squamous cell carcinoma. TGF- $\beta$ RII status was examined in laryngeal premalignant lesions coupled with malignant evolution and compared with a control group of similar lesions without progression to cancer.

Methods-Immunohistochemical staining for TGF- $\beta$ RII was performed on 15 paraffin wax embedded biopsies from patients with precancerous laryngeal lesions who subsequently developed invasive squamous cell carcinoma of the larynx, and on 30 control biopsies from patients who did not develop cancer in a comparable follow up period. In addition, DNA extracted from 18 preneoplastic lesions and eight squamous cell carcinomas was amplified by the polymerase chain reaction at the poly $A$ and the poly $G T$ regions of the TGF- $\beta$ RII gene.
\end{abstract}

Results-In the group of lesions with progression to carcinoma, 11 of 15 cases showed loss ( $<20 \%$ of epithelial cells) of TGF- $\beta$ RII immunoreactivity, whereas among non-evolved lesions only five of 30 had similar altered expression of the receptor ( $p<0.001$, two tailed Fisher's exact test). All squamous cell carcinomas showed a degree of receptor expression comparable with that of the corresponding preneoplastic lesion, with the exception of one case, in which loss of the receptor was evident only in invasive cancer. Mutation of the poly A sequence of the TGF- $\beta$ RII gene was identified in only one precancerous lesion and in the subsequent squamous cell carcinoma.

Conclusions-These findings indicate that the downregulation of TGF- $\beta$ RII is an early event in laryngeal carcinogenesis, which may result in the loss of TGF- $\beta$ mediated growth inhibition, thereby facilitating the progression of laryngeal precancerous lesions to squamous cell carcinoma.

(f Clin Pathol 2001;54:201-204)

Keywords: laryngeal cancer; transforming growth factor- $\beta$ type II receptor

Transforming growth factor $\beta$ (TGF- $\beta$ ) is a multifunctional cytokine that inhibits proliferation and induces differentiation of squamous epithelial cells. ${ }^{2}$ At least three isoforms of
TGF- $\beta$ have been identified in mammals, showing considerable sequence homology, similar binding characteristics, and similar in vitro biological activities. ${ }^{3}$ TGF- $\beta$ isoforms interact with specific receptor complexes formed by two different transmembrane proteins that belong to the serine-threonine kinase receptor family-the TGF- $\beta$ type I and II receptors (TGF- $\beta$ RI and TGF- $\beta$ RII, respectively). ${ }^{4} \mathrm{TGF}-\beta$ signalling requires the simultaneous presence of both TGF- $\beta$ RI and RII on the cell surface: in this heterodimeric complex TGF- $\beta$ RI becomes phosphorylated and activates downstream targets in the signal transduction pathway.

Several studies have indicated that the loss of TGF- $\beta$ RII expression is seen frequently in human carcinoma cell lines and this may result in resistance to TGF- $\beta$ mediated growth suppression, with relevant effects on the promotion of tumour growth. ${ }^{5-10}$ Frequent alteration of the TGF- $\beta$ RII gene has also been documented in vivo in colonic and gastric cancer arising in patients affected by DNA mismatch repair deficiencies, ${ }^{711}$ and altered expression of the receptor has been found in invasive breast cancer, prostatic adenocarcinoma, hepatocellular carcinoma, and thyroid carcinoma. ${ }^{13-16}$

Recently, the expression of TGF- $\beta$ RII has been examined extensively in squamous cell carcinoma of the head and neck region, and found to be frequently altered, with the reduction of receptor expression correlating with disease aggressiveness, whereas TGF- $\beta$ RI expression is mostly unaltered in these malignancies, as well as in the normal squamous epithelium and dysplatic epithelium adjacent to the invasive carcinoma. ${ }^{17}{ }^{18}$ However, the possible role of the downregulation of TGF- $\beta$ RII expression in the development of head and neck squamous cell carcinoma remains to be elucidated fully.

To examine the receptor status in the early phases of laryngeal carcinogenesis, we undertook a retrospective case control study using a series of biopsy specimens from patients with precancerous conditions of the larynx with and without progression to invasive squamous cell carcinoma. In addition, in a subset of cases we performed genetic analysis at two loci (two mutational hotspots) of the TGF- $\beta$ RII gene that are frequently altered in gastric and colonic adenocarcinomas arising in patients with DNA mismatch repair deficiencies. ${ }^{7}$

\section{Methods}

STUDY POPULATION

We selected 15 consecutive patients with precancerous laryngeal conditions who were 
treated by microlaryngoscopy and vocal cord stripping with biopsy, but who had received no further treatment except close follow up, and experienced a progression to squamous cell carcinoma of the larynx at least one year after the first biopsy. There were 13 men and two women, with a median age at initial diagnosis of 61 years (range, 37-73). The histological aspect of each lesion was reviewed, and an assessment of the epithelial modifications was made according to the criteria of Friedmann. ${ }^{19}$ There were seven cases of simple hyperplasia, four of mild dysplasia, two of moderate dysplasia, and two of severe dysplasia. The control group consisted of 30 patients with laryngeal lesions, age, sex ratio, morphology, and risk factor exposure (smoking history and alcohol consumption) comparable with those of the study population and who had no progression of the disease during a follow up period similar to that of the first group (median, 7 years; range 1.8-11 years), after initial microlaryngoscopy and vocal cord stripping with biopsy.

IMMUNOHISTOCHEMISTRY

The immunohistochemical studies were performed on formalin fixed, paraffin wax embedded sections, using the avidin-biotin complex technique (Dako, Milan, Italy). To identify alterations in TGF- $\beta$ RII expression, we used a rabbit polyclonal antibody that recognises an internal epitope of the receptor and is suitable for formalin fixed, paraffin wax embedded tissue sections (L-21; Santa Cruz Biotechnologies, Santa Cruz, California, USA). Negative controls were performed by substitution of the primary antibody with non-immune rabbit serum.

The results of the immunohistochemical staining were scored semiquantitatively, and a case was considered to show loss of TGF- $\beta$ RII expression when $<20 \%$ of epithelial cells showed a positive reaction.

\section{MICROSATELLITE ANALYSIS}

Serial paraffin wax sections $(12 \mu \mathrm{m}$ thick) obtained from 18 cases (eight with progression to squamous cell carcinoma and 10 without) with enough biopsy material to allow microdissection were placed on a glass slide and individually microdissected with the use of a dissecting microscope to separate epithelial cells from stromal cells. The same procedure was applied to serial sections of the eight squamous cell carcinomas that followed the preneoplastic lesions. Samples were collected into $1.5 \mathrm{ml}$ polypropylene tubes, containing $1 \mathrm{ml}$ xylene, incubated at $37^{\circ} \mathrm{C}$ for 15 minutes and pelleted at full speed in a microcentrifuge for 15 minutes. The xylene was then removed and the pellet was washed twice in absolute ethanol $(1 \mathrm{ml})$. The samples were thoroughly dried under a sterile hood and $100 \mathrm{ml}$ of digestion buffer, containing $1 \mathrm{M}$ Tris/ $\mathrm{HCl}(\mathrm{pH} 8.0)$, $0.5 \mathrm{M}$ EDTA, $0.02 \%$ Tween 20 , and $100 \mathrm{mg} /$ $\mathrm{ml}$ proteinase $\mathrm{K}$ (Quiagen Inc, Valencia, California, USA), was added to each tube. After an incubation of three hours at $55^{\circ} \mathrm{C}$, proteinase $\mathrm{K}$ was inactivated at $95^{\circ} \mathrm{C}$ for 10 minutes, and the samples were pelleted at full speed in a microcentrifuge. The supernatant was stored at $-20^{\circ} \mathrm{C}$ until use. For each polymerase chain reaction (PCR) $1 \mu \mathrm{l}$ of a $1 / 10$ dilution of each sample was used. The primers used for the molecular analysis were: RII U1, 5'-AGA TGCTGCTTCTCCAAAGTGC-3'; RII D1, 5'-TTGCACTCATCAGAGCTACAGG-3' for the poly(A) microsatellite sequence (nucleotides 709-718) and RII U2, 5'-ACTGAG TGCTGGGACCACG-3'; RII D2，5'-AGG AATCTTCTCCTCCGAGC-3' for the poly (GT) microsatellite sequence (nucleotides 1931-1936). ${ }^{20}$

The PCRs were carried out in a volume of $30 \mu \mathrm{l}$ and included template derived from paraffin wax sections, $1 \times$ PCR buffer, $1.5 \mathrm{mM}$ $\mathrm{MgCl}_{2}, 250 \mu \mathrm{M}$ of each dNTP, $0.5 \mathrm{U}$ Platinum $^{\mathrm{TM}}$ Taq DNA polymerase (Life Technologies, Rockville, Maryland, USA), and 3 pmol of each primer. The thermal profile was as follows: $94^{\circ} \mathrm{C}$ for two minutes, 35 cycles of $94^{\circ} \mathrm{C}$ for one minute, $56^{\circ} \mathrm{C}$ for one minute, and $72^{\circ} \mathrm{C}$ for one minute, then a final extension of $72^{\circ} \mathrm{C}$ for five minutes.

Amplified PCR fragments were analysed by $8-12 \%$ polyacrylamide gel electrophoresis and run at $20 \mathrm{~W}$ for three to four hours. Bands were detected by silver staining as described previously. ${ }^{21}$

STATISTICAL ANALYSIS

Two tailed Fisher's exact test was used to analyse the correlation between TGF- $\beta$ RII expression and clinicopathological features of the preneoplastic lesions.

\section{Results}

IMMUNOHISTOCHEMISTRY

Strong and diffuse immunostaining for TGF- $\beta$ RII was seen in normal structures present in laryngeal mucosa, such as vascular endothelial cells and mucous glands, which served as an internal positive control (fig 1). Considering the squamous epithelium, 16 lesions showed loss ( $<20 \%$ of cells) of receptor expression (fig 1). Preneoplastic lesions showing moderate or severe dysplasia tended to show more frequent loss of receptor expression in comparison with those showing simple hyperplasia or mild dysplasia $(66.6 \%$ v $42.8 \%)$, although the difference was not significant ( $p=0.5)$. In the group of precancerous lesions with progression to carcinoma, 11 of 15 cases showed loss $(<20 \%$ of epithelial cells) of TGF- $\beta$ RII expression (fig 1 ), whereas among lesions without evolution only five of 30 had similar altered expression of the receptor $(p<0.001$, two tailed Fisher's exact test).

In the group of squamous cell carcinomas, 12 of 15 cases showed loss of TGF- $\beta$ RII expression. Overall, there was a good correspondence with regard to loss of TGF- $\beta$ RII expression between preneoplastic lesions and subsequent squamous cell carcinomas-in only one instance did we observe loss of receptor expression ( $<20 \%$ of neoplastic cells) in the squamous cell carcinoma that was not evident in the corresponding preneoplastic lesion. 


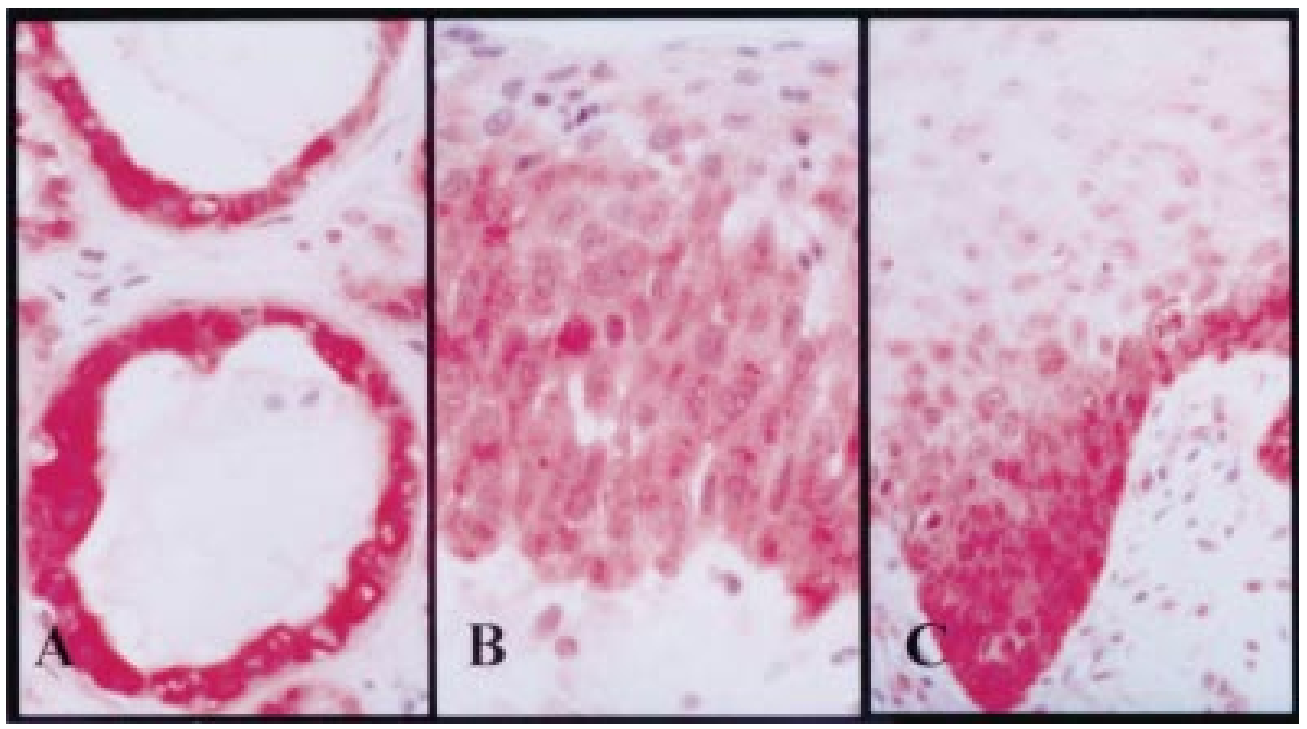

Figure 1 (A) Laryngeal mucous glands showing intense immunoreactivity for transforming growth factor $\beta$ (TGF- $\beta$ ) receptor type II. (B) Moderate laryngeal dysplasia with diffuse distribution of TGF- $\beta$ receptor type II in the basal and superficial layers of the squamous epithelium. This patient was free of disease five years after this biopsy. (C) Mild laryngeal dysplasia with pronounced loss of TGF- $\beta$ receptor type II expression: immunoreactivity is limited to the basal layers of the squamous epithelium. This patient developed a squamous cell carcinoma of the larynx three years later.

$\mathrm{N}$

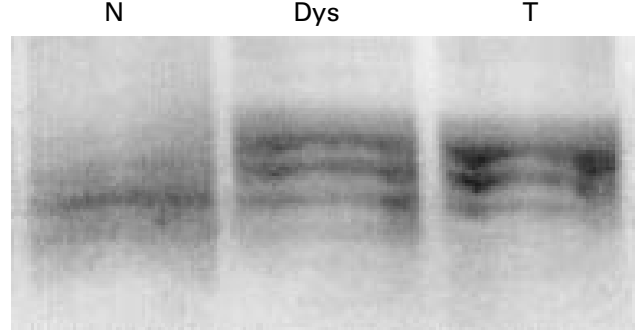

Figure 2 Microsatellite analysis of the transforming growth factor $\beta$ receptor type II (TGF- $\beta$ RII) poly A repeat sequence. Genomic DNA from normal tissue $(N)$, laryngeal dysplasia (Dys), and metachronous squamous cell carcinoma (T) was amplified by PCR, subjected to electrophoresis, and visualised with the silver staining method. Mutant bands are present in laryngeal dysplasia and in the subsequent squamous cell carcinoma.

ANALYSIS OF TGF- $\beta$ RII GENE

Of the 18 cases analysed, a mutation of the poly(A) sequence of the TGF- $\beta$ RII gene was identified in one precancerous lesion; the same alteration was present in the subsequent squamous cell carcinoma (fig 2). Tissue samples from these lesions showed loss of TGF- $\beta$ RII immunostaining. Conversely, the region of the GT repeat sequence was conserved in all cases examined.

\section{Discussion}

Our results confirm that the loss of TGF- $\beta$ RII expression occurs frequently in squamous cell carcinoma of the larynx, being present in $80 \%$ of cases. Such findings are comparable with those reported previously in head and neck squamous cell carcinomas, which presented pronounced or complete loss of the receptor in up to $90 \%$ of cases. ${ }^{17}$ In addition, the degree of receptor expression appeared to be inversely correlated with the degree of differentiation of the tumour and with the depth of the invasion. ${ }^{18} \mathrm{~A}$ similar reduction has been noted for TGF- $\beta$ RII mRNA in head and neck squamous cell carcinomas, thus indicating that the decreased protein concentrations depend upon abnormal gene transcription, and that a post-transcriptional mechanism is less likely to be responsible. ${ }^{182}$

To investigate whether anomalies of TGF- $\beta$ receptor expression are present in the early stages of laryngeal carcinogenesis and to assess their potential importance in the development of these tumours, we examined the TGF- $\beta$ RII status in laryngeal premalignant lesions coupled with malignant evolution in comparison with a control group of similar lesions without progression to cancer. According to our analysis, the frequency of loss of TGF- $\beta$ RII is much higher in preneoplastic lesions with subsequent progression to cancer than in those without evolution, indicating that this event may have an important role in the development of squamous cell carcinoma of the larynx. Indeed, disregulation of the TGF- $\beta$ pathway could cooperate with other genetic changes, such as alterations of $\mathrm{p} 16, \mathrm{p} 53$, and cyclin D1 expression in the early phases of laryngeal carcinogenesis. ${ }^{23}{ }^{24}$ All these events involving key regulators of the cell cycle could result in alteration of growth control of epithelial cells, finally leading to cancer promotion.

Several mechanisms might be responsible for TGF- $\beta$ RII gene silencing in cancer. First, this gene contains two microsatellite loci that are frequently altered in colorectal and gastric cancers arising in patients with DNA mismatch repair deficiencies. These mutations, however, are quite rare or absent in sporadic carcinomas of the uterine cervix, pancreas, and in squamous cell carcinomas of the head and neck. ${ }^{22}$ 25-27 In accordance, in our series we could find only one such alteration involving the polyadenine region, which occurred in one preneoplastic lesion and in the subsequent squamous cell carcinoma.

Therefore, other genetic alterations are likely to occur in head and neck squamous cell carcinomas, which may explain the high frequency 
of the loss of receptor expression. Human head and neck squamous cell carcinoma cell lines have been shown to contain $\mathrm{G}: \mathrm{C} \rightarrow \mathrm{C}: \mathrm{G}$ transversions in the kinase domain of TGF- $\beta$ RII, which may alter TGF- $\beta$ RII activity, leading to resistance to the inhibitory control of TGF- $\beta .^{8}$ Missense mutations and deletions of the serine/threonine kinase domain of TGF- $\beta$ RII have also been identified in six of 28 head and neck squamous cell carcinomas in vivo. ${ }^{27}$ Finally, an alternative mechanism that might lead to altered expression of the gene is hypermethylation within the promoter or other transcription regulatory sequences, which has been documented to occur in oesophageal carcinomas. ${ }^{27}$ Further studies using fresh tissue samples will be necessary to determine the contribution of these mechanisms to TGF- $\beta$ RII gene inactivation in laryngeal preneoplastic lesions and squamous cell carcinomas.

In conclusion, our findings indicate that precancerous laryngeal lesions frequently show altered expression of TGF- $\beta$ RII, with a clear prognostic relevance for tumour progression, thus underlining the potential role of TGF- $\beta$ RII immunostaining in the assessment of the risk for evolution of preneoplastic laryngeal lesions. If this is confirmed in prospective studies with larger patient populations, TGF- $\beta$ RII immunostaining could be included among the biomarkers potentially useful for selecting patients for chemoprevention ${ }^{28}$ or for endoscopic screening protocols.

1 Coffey RJ, Bascom CC, Sipes NJ, et al. Selective inhibition of growth-related gene expression in murine keratinocytes of growth-related gene expression in murine keratinocytes
by transforming growth factor $\beta$. Mol Cell Biol by transformin

2 Reiss M, Sartorelli AC. Regulation of growth and differentiation of human keratinocytes by type $\beta$ transforming growth factor and epidermal growth factor. Cancer Res 1987;47:6705-9.

3 Roberts AB, Sporn MB. Peptide growth factors and their receptors. In: Roberts $\mathrm{AB}$, Sporn $\mathrm{MB}$, eds. Handbook of experimental pharmacology. Heidelberg: Springer-Verlag, 1990:419-72.

$4 \mathrm{Hu}$ PP, Datto MB, Wang X. Molecular mechanisms of transforming growth factor-signaling. Endocr Rev 1998;19: 349-63.

5 Reiss M, Stash EB. High frequency of resistance of human squamous carcinoma cells to the anti-proliferative action of transforming growth factor- $\beta$. Cancer Commun 1990;2: 363-9.

6 Park K, Kim S-J, Bang Y-J, et al. Genetic changes in the transforming growth factor $\beta$ (TGF- $\beta$ ) type II receptor transforming growth factor $\beta$ (TGF- $\beta$ ) type II receptor gene in human gastric cancer cells: correlation with
sensitivity to growth inhibition by TGF- $\beta$. Proc Natl Acad sensitivity to growth inhibition
Sci U S A 1994;91:8772-6.

7 Markowitz S, Wang J, Myeroff L, et al. Inactivation of the type II TGF- $\beta$ receptor gene in colon cancer cells with genomic instability. Science 1995;268:1336-8.

8 Garrigue-Antar L, Muñoz-Antonia T, Antonia SJ, et al. Missense mutations of the transforming growth factor $\beta$ type II receptor in human head and neck squamous carcinoma cells. Cancer Res 1995;55:3982-7.
9 Norgaard P, Damstrup I, Rygaard K, et al. Growth suppression by transforming growth factor $\beta 1$ of human small-cell lung cancer cell lines is associated with expression of the type II receptor. Br f Cancer 1993;69:802-8.

10 Kalkhoven E, Roelen BA, de Winter JP, et al. Resistance to transforming growth factor $\beta$ and activin due to reduced receptor expression in human breast tumor cell lines. Cell Growth Differ 1995;6:1151-61.

11 Parsons R, Myeroff LL, Liu B, et al. Microsatellite instability and mutations of the transforming growth factor $\beta$ type II receptor gene in colorectal cancer. Cancer Res 1995;55: 5548-50.

12 Myeroff LL, Parsons R, Kim SJ, et al. A transforming growth factor $\beta$ receptor type II gene mutation common in colon and gastric cancer but rare in endometrial cancers with microsatellite instability. Cancer Res 1995;55:5545-7.

13 De Jong JS, van Diest PJ, Van der Valk, et al. Expression of growth factors, growth inhibiting factors, and their receptors in invasive breast cancer. I: An inventory in search of autocrine and paracrine loops. F Pathol 1998;184: $44-52$.

14 Guo Y, Jacobs SC, Kypranou N. Down-regulation of protein and mRNA expression for transforming growth factor- $\beta 1$ (TGF- $\beta 1$ ) type I and type II receptors in human prostate cancer. Int $\mathcal{F}$ Cancer 1997;71:573-9.

15 Lazzereschi D, Ranieri A, Mincione G, et al. Human malignant thyroid tumors displayed reduced levels of transforming growth factor $\beta$ receptor type II messenger RNA and protein. Cancer Res 1997;57:2071-6.

16 Furuta K, Misao S, Takahashi K, et al. Gene mutation of transforming growth factor $\beta 1$ type II receptor in transforming growth factor $\beta 1$ type II receptor

17 Eisma RJ, Spiro JD von Biberstein SE, et al. Decreased expression of transforming growth factor $\beta$ receptors on head and neck squamous cell carcinoma tumor cells. Am $\mathcal{F}$ Surg 1996;172:641-5.

18 Muro-Cacho CA, Anderson M, Cordero J, et al. Expression of transforming growth factor $\beta$ type II receptors in head and neck squamous cell carcinoma. Clin Cancer Res 1999;5:1243-8.

19 Friedmann I. Precursors of squamous cell carcinoma. In: Ferlito A, ed. Surgical pathology of laryngeal neoplasms. London: Chapmann and Hall, 1996:107-21.

$20 \mathrm{Lu} \mathrm{SL}$, Akiyama Y, Nagasaki H, et al. Mutations of the transforming growth factor- $\beta$ type II receptor gene and genomic instability in hereditary nonpolyposis colorectal cancer. Biochem Biophys Res Commun 1995;216:452-7.

21 Dockhorn-Dworniczak B, Dworniczak B, Brommelkamp L, et al. Non-isotopic detection of single strand conformation polymorphism (PCR-SSCP): a rapid and sensitive technique in diagnosis of phenylketonuria. Nucleic Acid Res nique in diag

22 Wang D, Song H, Evans JA, et al. Mutation and downregulation of the transforming growth factor $\beta$ type II receptor gene in primary squamous cell carcinomas of the head and neck. Carcinogenesis 1997;18:2285-90.

23 Gallo O, Santucci M, Franchi A. Cumulative prognostic value of p16/CDKN2 and p53 oncoprotein expression in cancer risk assessment of premalignant laryngeal lesions. $\mathscr{F}$ Natl Cancer Inst 1997;89:1161-3.

24 Uhlman DL, Adams G, Knapp D, et al. Immunohistochemical staining for markers of future neoplastic progression in the larynx. Cancer Res 1996;56:2199-205.

25 Chu TY, Lai JS, Shen CY, et al. Frequent aberration of the transforming growth factor- $\beta$ receptor II gene in cell lines but no apparent mutation in pre-invasive and invasive carcinomas of the uterine cervix. Int $\mathcal{F}$ Cancer 1999;80:50610 .

26 Goggins M, Shekher M, Turnacioglu K, et al. Genetic alterations of the transforming growth factor beta receptor genes in pancreatic and biliary adenocarcinomas. Cancer Res 1998;58:5329-32.

27 Garrigue-Antar L, Souza RF, Vellucci VF, et al. Loss of transforming growth factor- $\beta$ type II receptor gene exprestransforming growth factor- $\beta$ type II receptor gene expres-
sion in primary human esophageal cancer. Lab Invest 1996; sion in prim

28 Hong WK, Lippman SM, Hittelma WN, et al. Retinoid in the chemoprevention of aerodigestive cancer: from basic research to the clinic. Clin Cancer Res 1995;1:677-86. 